American Journal of Economics and Business Administration 1 (3): 257-262, 2009

ISSN 1945-5488

(C) 2009 Science Publications

\title{
Development or the Environment
}

\author{
Sumit Kumar Jaiswal \\ Department of Ballb, Kiit University, Kiit Law School Bhubhuneswar, Orissa, \\ The University-Kalinga Institute of Industrial Technology Kalinga Law School, Krishna Campus-7, \\ Patia Road, Bhubaneswar-751024, India
}

\begin{abstract}
Problem statement: The relationship between trade and environment is very complex though development and environment are invariably related to each other. There is a close relationship between development and conservation of the environment. The relationship between the WTO and MEAs is reducing and eliminating barriers to trade in environmental goods and services. This relation was acknowledged in 1972 Stockholm Conference on Human Environment. Over the past 20 years, an extraordinary number of international environmental agreements have been concluded. Very few MEAs actually regulate trade or contain trade-related provisions. Theoretically, MEA trade measures and WTO rules can and should interact in a positive and synergistic way. Approach: The main aim of this paper/research is to find out whether the international law has any method of dispute resolution or a systematic approach towards the ongoing debate between the environment and trade which is interlinked in a very complex manner. The resolution of these complex inter-linkages has become a challenge which we have to face. Results: The author had tried to highlight the complex relationship of WTO-MEA where both the environment and trade policy makers prefer unilateral solution for the environmental problem. Resorting to such unilateralism can pose a risk of arbitrary discrimination. The source of the conflict between the WTO and MEAs lies within the measures contained in MEA's and WTO rules. For example, the violation of WTOs non-discrimination principle by MEAs. The two vital questions that occurred were whether trade measures under multilateral environmental agreements are compatible with WTO rules and If MEA-related disputes are brought to the WTO system, should the WTO discourse on the relationship between the WTO and MEAs? Conclusion: Both trade and environment are crucial for the well being of human society. What is most important is to strike a proper balance between free trade and environmental protection. There are a large number of multilateral environmental agreements. Although Special Trade Obligations (STOs) can be found in only a minority, these MEAs usually incorporate environmental norms that may result in clashes with trade norms of the WTO. One of the major steps is to control trade, as it is contributing to environmental damage. The other is by providing additional incentives to join MEAs and restricting non-parties to trade with parties in restricted goods. e.g., Montreal Protocol bans trade with non-parties in ozone-depleting substances. If a conflict arise in the future between the WTO Agreements and other rules of international law, WTO dispute settlement bodies will have to consider recognized rules under public international law to settle the conflict. In the context of a dispute between two WTO members, any WTO member that considers that any of its WTO benefits have been nullified or impaired it has an absolute right to trigger the WTO dispute settlement mechanism and request consultations and the establishment of a panel.
\end{abstract}

Key words: Inter-linkages, multilateral trade agreements, development, world trade organization

\section{INTRODUCTION}

Our world has seen fundamental and pervasive change in the last 50 years. National economies are increasingly integrated in a global economic structure. The world has also seen enormous environmental change. Global carbon dioxide emissions have quadrupled, and the steady increase in nitrogen releases from cars and fertilizers is creating deserts of lifelessness in our oceans and lakes. In the last 15 years alone 11 major multilateral environmental agreements have entered into force. Initial concerns about the effect that increased trade would have on the environment emerged at the beginning of the 1970s, the same time the environmental movement in the industrialized states begins gaining strength. 
Trade and environment issues started gaining mainstream attention in the beginning of the 1990s, in the Tuna/Dolphin decision. The topic stayed in front of the public throughout the 1990s because in 1998, the WTO again ruled against a US ban on shrimp imports caught without Turtle Excluder Devices (TEDs). These two cases show how process, the issue of how goods are produced, can stir up trade and environmental problems. The current rules of the game in the international trading arena are also problematic with respect to many international environmental treaties ${ }^{[1]}$.

World trade organization: The World Trade Organization (WTO) is a consensus-based organization formed to provide a common institutional framework for the conduct of trade relations among its Members in matters related to the agreements and associated legal instruments. The agreements referred to in Agreement Establishing the WTO form the basis for the WTO's multi-lateral trading system. These agreements began with the General Agreement on Tariffs and Trade of 1947 and include subsequent amendments made throughout the years and culminating in the Uruguay Round agreements ${ }^{[2]}$.

Multilateral environmental agreements: MEAs are those agreements with more than two parties: The word "multilateral" has a slightly different meaning for the trade community, for whom the multilateral trading system is the global trading system. As a result of the comprehensive coverage of the WTO agreements and the principles of most favored nation and prohibition of national treatment, the status of multilateral environmental agreement with trade related provisions has come under scrutiny. Multilateral environmental agreements that impact trade co-exist with the WTO trading system under general exceptions found in Article XX. More than 200 multilateral environmental agreements are known to exist. Of the 20 are of notable significance to the environment-trade ${ }^{[2]}$.

Seven MEAS that are particularly relevant to trade: The convention on international trade in endangered species: 'The earliest of the key MEAs, CITES was drawn up in 1973 and entered into force two years later. CITES seeks to regulate trade in certain species and their parts, as well as products made from such species. CITES has long been known for the unusually active participation of non-governmental organizations, scientific and advocacy organizations in particular, in its deliberations.

The Vienna convention and the Montreal protocol: The Vienna Convention was concluded in 1985. It provided for research and cooperation to better understand the issue, and formed a framework agreement under which specific protocols could be negotiated as needed. The evidence soon became stronger, and in 1987 the Parties drafted the Montreal Protocol, establishing a regime of control for several classes of industrial chemicals now known to harm the stratospheric ozone layer. The result has been a ban on the production and use of several industrial chemicals, together with severe limitations on others. It has successfully implemented a precautionary approach, by acting before the availability of clear scientific evidence, and that of common and differentiated responsibility, by establishing a fund to assist developing countries in their transition away from the use of controlled substances.

The Basel convention: The Basel convention resulted from the concern of developing countries, particularly in Africa, that they could become the dumping ground for hazardous wastes whose disposal in the developed world had become difficult and expensive. Developing countries and non-governmental organizations have played a significant role in the regime since its inception. Parties have adopted an amendment banning the export of hazardous waste from mainly OECD to non-OECD countries (the Basel Ban) and a protocol on liability and compensation, both of which have yet to enter into force even though numerous countries currently adhere to them.

Convention on biological diversity and the Cartagena protocol: The Convention's objective is conserving biological diversity, the sustainable use of its components and the fair and equitable sharing of the benefits arising from the use of genetic resources. The Convention has produced the landmark Cartagena Protocol on Bio-safety. Cartagena is a Protocol to the CBD, covering trade in most forms of Living genetically Modified Organisms (LMOs) and the risks it may present to biodiversity. It sets out a procedure for countries to decide whether to restrict imports of LMOs.

United Nations framework convention on climate change and the Kyoto protocol: The UNFCCC was adopted at the Rio Conference in 1992, it aims to stabilize the emission of various greenhouse gases (such as carbon-dioxide or methane) that contribute to global climate change. Although neither the UNFCCC nor the Kyoto Protocol includes trade-related provisions, it is highly likely that the parties, in fulfilling their Kyoto obligations, will adopt domestic 
policies and measures with significant trade implications. (UNFCCC: 189 parties, Kyoto Protocol: 155 parties).

Rotterdam convention: The Rotterdam Convention is designed to help countries monitor and control trade in certain hazardous chemicals. The PIC regime offers assurance that information will be provided quickly, and that it will reach the appropriate authorities when needed.

Stockholm convention: The POPS Convention entered into force in May 2004. It establishes an international regime for the control of certain substances that persist in the environment and can accumulate in the food chain, all of which are suspected of disrupting hormonal functions in animals and humans (such chemicals are known as endocrine disruptors). The POPS Convention also establishes a procedure for adding to these annexes.

The WTO-mea relationship: The Doha Declaration mandates negotiations on the relationship between existing World Trade Organization (WTO) obligations and "Specific Trade Obligations" (STOs) set out in Multilateral Environmental Agreements (MEAs). Some MEAs have STOs, which may lead to the application of trade restrictions or prohibitions.

Firstly, the public policy goal is to protect human, animal or plant life or health is defined by the MEA. Apparently international cooperation is required because national measures are insufficient.

Secondly, the WTO equipped to examine cases that are technically complex and involve policies other than trade. At present, MEAs have weak dispute settlement systems, partly because compliance problems are usually related to capacity or resource constraints, which are better addressed through cooperation and technical and financial assistance programs. With stronger dispute settlement provisions in MEAs, controversies over the "necessity" of a domestic measure, in all probability, would be examined by that specialized forum rather than the $\mathrm{WTO}^{[1]}$.

The trade-MEA relationship has three distinct components. Firstly, it can have an impact on MEAs which may at trade directly or indirectly. For example, the Montreal Protocol on Ozone Depleting Substances directly stops trade in certain types of products. It also has changes in production processes that previously used ozone-depleting substances, in effect excluding from trade products produced in the old ways. This type of trade- impact, is a natural result of banning or restricting environmentally damaging products or processes and is in fact, the central purpose of those measures.

Secondly, the potential for trade liberalization to affect the subject matter of MEAs. For example, liberalizing trade in computer chips might have repercussions for the objectives of the Montreal Protocol.

Thirdly, is related to the legal and policy relationship between the body of law represented in the MEAs and the body of law represented in trade and investment agreements.

Constraint of the discussion in the WTO: As previously stated, environmental issues were taken up in the GATT/WTO as a result of numerous developments at the international level in trade and environmental fora. The developed countries were pressurized to reconcile between trade and environmental policies, developing countries feared that a new "green" conditionality would be attached to market access opportunities ${ }^{[3]}$.

The scope of WTO ignores NTCs (Non-Trade Concerns): WTO Members recognize, however, that the WTO is not an environmental protection agency and that it does not aspire to become one. They believe that trade and environmental policies can complement each other. Environmental protection preserves the natural resource base on which economic growth is premised, and trade liberalization leads to the economic growth needed for adequate environmental protection. To address this, the WTO's role is to continue to liberalize trade, as well as to ensure that environmental policies do not act as obstacles to trade, and that trade rules do not stand in the way of adequate domestic environmental protection.

Basic obligations under the WTO rules and environmental exceptions: GATT 1994 is primarily founded on principles of free trade. As per Article I and III of the GATT provisions the principle of mostfavored nation states that if a country is granting special favor, than that country has to do the same for all its trading partners, whereas according to the principle of national treatment, imported and locally-produced goods should be treated equally.

Non-discrimination is the main principle on which the multilateral trading system. It assures unsurprising access to markets, protects the economically weak from the powerful, and guarantees consumer choice.

The elimination of the quantative restrictions as per Article XI of the GATT 1994 which addresses the elimination through quotas, import or export licenses, 
or other measures, introduced or maintained by countries on the importation or exportation of products. The main purpose of omission such restriction is to encourage countries to convert them into tariffs, which are more transparent and less likely to misrepresent trade.

The "General Exceptions" provision of the GATT 1994, Article XX, constitutes conditional exceptions to GATT obligations. In Articles I, III and XI. The word "environment" is not used, Article XX can be applied to justify environmentally inspired rules that crash with trade.

WTO had amplified market admittance for developing countries: From the point of view of developing countries, where poverty is most important obstacle to environmental protection, the opening up of world markets to their exports is essential. As many developing and least-developed countries are heavily dependent on the export of natural resources for foreign exchange earnings, trade liberalization is expected to improve allocation and more efficient use of their resources.

The coordination between trade and environment should be enhanced: 'In addition, it is widely recognized that multilateral cooperation through the negotiation of MEAs constitutes the best approach for resolving transboundary environmental concerns. UNCED clearly sanctioned consensual and cooperative multilateral environmental solutions to global environmental problems ${ }^{[3]}$.

An overview relating to the disputes decided by the WTO: Six panel proceedings of GATT which involved an examination of environmental measures or human health-related measures under Article XX were completed. Six of them occurred under the GATT, and five under the $\mathrm{WTO}^{[4]}$.

Mexico against United States, the tuna dolphin case: In Tuna Dolphin I case a GATT Panel declared a US embargo on tuna caught by fishing methods causing high dolphin mortality to be illegal. This case created an explosive academic debate and was the catalyst for an intense clash between trade specialists and environmentalists.

Under the Marine Mammal Protection Act (MMPA) the importation of commercial fish or products from fish which have been caught with commercial fishing technology which results in the incidental kill or serious injury of ocean mammals in excess of US standards were prohibited. The importation of yellowfin tuna harvested with purseseine nets in the ETP was Prohibited (primary nation embargo) as per the US Marine Mammal Protection Act, the United States had adopted a unilateral ban on imports of yellow-fin tuna using fishing methods that killed dolphins, a protected species under the MMPA.

According to the Mexico's complaint to the GATT the dispute settlement Panel founded the US tuna embargo violating GATT Article XI, XII and III which prevent measures prohibiting or restricting exports or imports. The United States appealed the Panel to find that the direct embargo was consistent with Article III and alternatively it was covered by Article XX(b) and (g). They also argued that the intermediary nation embargo was dependable with Article III and it was justified under Article XX.

The GATT Panel founded that the import prohibition under the direct and the intermediary embargoes did not comprise of the internal regulations within the meaning of Article III. It was conflicting with Article XI:1 and was not justified by Article XX paragraphs (b) and (g). Moreover, the intermediary embargo was not justified under Article XX(d). As the MMPA regulation which alarm harvesting techniques that could not possibly affect tuna as a product, the ban on tuna could not be justified.

This holding was restated by the second GATT panel namely the Tuna-Dolphin II decision, concerning the legality of a secondary embargo on tuna products from countries that processed tuna caught by the offending countries. Neither decision was binding under the GATT because both were not adopted by the contracting parties. Much of the interpretation in the Tuna Dolphin cases has been efficiently overruled later on $^{[3]}$.

B. Shrimp-turtle case: 'After the WTO was launched in 1995, it was asked again to look at a similar dispute, known as the "Shrimp-Turtle" case.

The US Endangered Species Act of 1973 listed as the five species of sea turtle as endangered. The Act requires that US shrimp trawlers use "turtle excluder devices" (TEDs) in their nets when fishing in areas where there is a significant likelihood of encountering sea turtles. The complainants alleged that the US import ban violated Articles I, XI and XIII of GATT 1994.

The Panel found that the import ban on shrimp and shrimp products as applied by the United States is inconsistent with Article XI:1 of the GATT 1994, limiting the use of import prohibitions or restrictions, and could not be justified under GATT Article XX. The US lost the case because it had discriminated between countries as it provided technical and financial 
assistance to the Western hemisphere (mainly Caribbean). It did not give the same advantages, to the four Asian countries that filed the complaint with the WTO.

The 'Shrimp-Turtle' case is a clear indication of the fact that GATT Article XX (b) and provided that the measures are not discriminatory in nature. The "Shrimp-Turtle" decision somewhat satisfied the environmentalists, because it found that the United States could invoke the exception even without being party to an MEA, so long as it acted in a nondiscriminatory fashion ${ }^{[4]}$.

C. Canada against European Union, the asbestos dispute: 'Chrysotile asbestos is a highly toxic material, exposure to this causes large risks to human health. It has been extensively used in various industrial sectors. The French Government imposed a ban on the substance as well as on products that contained it. Canada had contested this prohibition through the WTO claiming that the Decree violated GATT Articles III: 4 and XI. The European Community (EC) requested the panel to confirm that the Decree was either compatible with Article III: 4 or necessary to protect human health within the meaning of Article XX (b). The panel ruled in favor of the EC. Article III, requires countries to grant equivalent treatment to like products. According to the Panel the French ban could be justified under Article XX (b) whereas the EC ban was a violation. This ruling is a clear indication that the WTO dispute settlement mechanism would uphold any measure by the member states to protect the environment so long as it does not constitute a means of arbitrary or unjustifiable discrimination or a disguised restriction on international trade $\mathrm{e}^{[3]}$.

Challenges in front of international law with some remedial measures to reconcile the dispute between trade and environment: The vital questions that occurred were whether trade measures under a multilateral environmental agreement are compatible with WTO rules. For example, an MEA could authorize trade in a specific product between its parties, yet ban trade in the same product with countries that have not signed the agreement. This could be contrary with WTO's non-discrimination principle known as "mostfavored-nation treatment", which requires countries to grant equivalent treatment regarding same (or "like") products imported from any WTO member country. If MEA-related disputes are brought to the WTO system, should the WTO discourse on the relationship between the WTO and MEAs? No, WTO dispute resolution panel has yet addressed the conformity of any MEA trade restrictions with GATT rules. To date, several GATT (pre-WTO) or WTO dispute panels have challenged domestic environmental regulations, but thus far, multilateral environmental agreements have not come under the scrutiny of a WTO dispute panel ${ }^{[4]}$.

One of the major uses is to control trade itself, where trade is perceived to contribute directly to the environmental damage. Another use is to improve the effectiveness of an agreement. They can provide an additional incentive to join and adhere to the MEA by restricting (often barring) non-parties from trading in restricted goods with parties (though there are usually exceptions for non-Parties with legislation that meets the MEA standards of protection). The Montreal Protocol, for example, bans trade with non-parties in ozone-depleting substances and products containing them, a provision that many observers agree was crucial to the wide international support the Protocol has achieved. Without such measures, the agreement would be easily scuttled by non-parties increasing production of the restricted goods and shipping them to the parties that have restricted their own production-a perverse result both environmentally and economically.

'Since the World Trade Organization is a subject of international law with the members being primarily sovereign States, the law of the WTO is international law, albeit a special type. The sources of international law as laid down in Article 38(1) of the Statute of the International Court of Justice. All the multilateral trade agreements annexed to the Agreement Establishing the WTO are known as the 'WTO agreements' or 'covered agreements' are the fundamental source of law. If a Conflict arise in the future between the WTO Agreements and other rules of international law, be they conventional or customary, WTO dispute settlement bodies will have to consider recognized rules under public international law to settle the conflict.

\section{CONCLUSION}

In recent years, the increase in both the number of treaties and the number of State parties to these treaties has given rise to the crucial issue of conflicting obligations under these treaties. Therefore, when drafting a new treaty, it is preferable to include express provisions as to its relationship with other treaties including future treaties. Such a provision is called a 'conflict clause' by the International Law Commission. As prevention is better than a cure, in practice, a number of multilateral treaties contain such a conflict clause governing their relationship with earlier or later treaties, or both. A popular provision of this kind is that "the treaty prevails over all other treaties, past and future ${ }^{[4]}$. 
Am. J. of Economics and Business Administration, 1 (3): 257-262, 2009

\section{REFEENCES}

1. Najam, A., 2007. Trade and environment-a recourse book.

http://www.iisd.org/pdf/2007/trade_and_env.pdf

2. Leslie M. and P.E. Hill, 2000. Conflict between the world trade organization, the European community and environmental protection: A matter of principles.

http://www1.american.edu/TED/class/karin/karin3. $\mathrm{htm}$
3. WTO Secretariat, 2004. Trade and environment at WTO.

http://www.wto.org/english/res_e/booksp_e/trade_ env_e.pdf

4. Hamid, A.G., K.M. Sein and N.A.K. Nik Mahmod, 2008. The WTO rules versus multilateral environmental agreements: The search for reconciliation.

http://staff.iiu.edu.my/ghafur/Published\%20Article s/WTO\%20Rules\%20versus\%20Multilateral\%20E nvironmental\%20Agreements.pdf 